\title{
EXPLORING SENIOR HIGH SCHOOL STUDENTS' SELF-REGULATION IN FACING THE ENGLISH HIGH-STAKE UNIVERSITY ADMISSION TEST
}

\author{
Arima Renny Dayu Putri \\ Sanata Dharma University, Yogyakarta \\ rimarenny@gmail.com \\ Paulus Kuswandono \\ Sanata Dharma University, Yogyakarta \\ kus@usd.ac.id
}

\begin{abstract}
This study investigated the implementation of senior high school students' self-regulation in facing the high-stake university admission test. The researchers examined the factors that constitute senior high school students to be self-regulated learners and how the students implemented self- regulation in achieving their goals as well as entering a university. To obtain the data, the researchers conducted the study in a public one senior high school in Klaten, Indonesia using mix methods of qualitative and quantitative research. The researchers gained the data by interviewing 12 third grades of senior high school students and asking them to answer questionnaires. The researchers presented the data using narrative inquiry statements. The result showed that all participants did self-regulation learning in order to achieve their goals to enroll study at a famous and reputable university in Indonesia such as ITB, UGM, UNS, STAN and POLITEKES. To be self-regulated learners, the participants had implemented 4 conditioned phases such as forethought and planning, monitoring, controlling and reflecting phase.
\end{abstract}

Keywords: Self-regulated learners, high-stake university admission test, English test, senior high school students

\section{INTRODUCTION}

To be truly successful in passing the high-stake university admission test, senior high school students had to prepare and manage their study as well as being self-regulated learners. The phenomenal and challenging event for senior high school students happens in the final year of their study. The higher education as well as University entrance test waited for them. They faced the high-stake university admission test to ensure that the university accepts only the best students. A high-stakes test is any test used to make important decisions about students, educators, schools, or districts, most commonly for the purpose of accountability-i.e., the attempt by federal, state, or local government agencies and school administrators to ensure that students are enrolled in effective schools (The Glossary of Education Reform). All of the tests were by all means in the context of competition.

There were some kinds of compulsory materials tested including English as a foreign language in Indonesia. It becomes a compulsory test. It is considered as a foreign language since people do not commonly use it as their daily spoken language (Wold, 2006). Leaver, Ehrman, and Shekhtman, (2005) define that for some reasons, schools require students to 
study a foreign language such us English, determine how well the students can successfully perform in the university courses. Thus, English as a foreign language becomes one of the materials tested in the high-stake university admission test. It became the challenging part of the University entrance test. This kind of requirement made them aware the significance of the English test.

In relation to the University entrance test, there had been a research done by Çırak (2016) about senior high school students' feelings and thoughts to enroll the University entrance test. The result of his study identified that there were three main themes of students' feelings and thoughts, 1) anxiety, 2) family expectations and responsibilities, and 3) the door to the future. Çrak (2016) describes that the participants felt afraid, desperate, and helpless and panic as the categorization of anxiety. They also mentioned that the family expectation was like a heavy burden on their shoulders. And the universities they enrolled will be the determination of their future job.

On the other hand, the awareness of facing the examination made students to be responsible to study. They not only were motivated to explore themselves to meet the demands of the English test, but they also had to study hard in facing the English test and struggled in achieving their goals. As confirmed by Schunk, Meece, and Pintrich (2002), motivation is the process whereby goal-directed activity is instigated and sustained. It is a process which affects both new learning and the performance of previously learned skills, strategies and behaviors. Students' motivation is related with students' goals as well as their action or effort for engaging their achievement context. Students who set their goals in their learning is categorized as Self - regulated learners. The definition of Self-Regulated students according to Zimmerman (1989) is the degree of students who are metacognitive, motivationally and behaviorally active participants in their own learning process. In this study, the senior high school students were supposed to be self-regulated learners when they were preparing themselves to face and follow the high-stake university admission test. Academic self-regulation refers to self-generated thoughts, feelings, and actions intended to attain specific education goals, such us analyzing an assignment, preparing to take a test, or writing a paper (Zimmerman, Bonner, \& Kovach, 1996).

A framework proposed by Pintrich (2000b) defines four phases of self- regulation, namely forethought, monitoring, control and reflection. During each of these phases there are four possible areas of self-regulation involving cognition, motivation, behavior and context.

Table 1. A Framework Proposed by Pintrich (2000b)

\begin{tabular}{ll}
\hline Phases of Self - Regulation & Activities \\
\hline Forethought and Planning & Goal setting, metacognitive knowledge, self-efficacy, study plan \\
\hline Monitoring & $\begin{array}{l}\text { Metacognition awareness, awareness of self-efficacy, time } \\
\text { management }\end{array}$ \\
\hline Controlling & Controlling strategies, maintaining motivation, \\
\hline Reflecting & Cognitive judgment, assessing motivation, keep doing exercise. \\
\hline
\end{tabular}


In the first phase, self-regulated learners planed their own goals of studying, measured their potential in mastering a lesson before conducting a study regulation, believing that they can achieve their own goal and making an appropriate study plan. According to Bandura (1986, 1989) as quoted by Abun (2018), achieving certain goals can be affected by several factors such us self-efficacy, possible selves and self-awareness. Self- efficacy is imperative in the process of achieving certain goals. In addition, one's dreams or wishes can also motivate students to reach a certain target. According to Markus et al $(1985,1989)$ as quoted by Abun (2018) self-efficacy may be an important aspect in self-regulation; however, selfregulation is also affected by one's dream of what he wants to be in the future or a possible self that one wants to be in the future.

In the monitoring phase, self-regulated learners monitored their learning strategies, motivation and time management. Anderson (2002) states that metacognitive ability to select, use, and monitor particular strategies in a given context for a specific purpose means that the learner can think and make conscious decisions about their own learning processes. In this case students monitored the progress of their learning whether they had improvement in learning or not.

The third phase is controlling phase in which students did metacognitive strategies and maintained their motivation. According to Mcfarland (2013), metacognitive strategies are a sequential action that requires developing a controlling action. In addition, according to Wilson (1999) as quoted by Mcfarland (2013) students control their knowledge about the content knowledge, personal learning strategies and what has been done and needs to be done.

The last phase is evaluating phase, students conducted metacognitive judgment. They evaluated their strategies whether they would change their strategies or not. According to Schraw and Dennison (1994) as quoted by Mcfarland (2013), students with self-regulation study do better at paying attention, they use learning strategies more effectively, and they are more conscious when they are not comprehending some topics they are trying to find ways to learn them better.

As mentioned by Ames (1992), students who implemented a performance-goal orientation are motivated to learn through the desire to reach their competence ability. Students who were motivated to enroll in the high-stake university admission test were expected to be self- regulated learners who evaluate and monitor their capability, set their goal, plan strategies, implement strategies and monitor the outcome (Zimmerman et al., 1996). Seker (2016) conducted a research to investigate the importance of Self-regulated learning (SRL) in language teaching by exploring its influence on language achievement. He gained data from 222 undergraduate foreign language learners at a state university using quantitative analysis. The study found that the participants were at a moderate level in using the Self-regulated learning method, especially on cognitive and metacognitive strategies. However, the results of this study indicated that Self-regulated learning was important and significant ways of predicting language achievement. In addition, being Self-regulated 
learners can also predict what learning methods should be used to achieve the desired language skills target.

Moreover, Mahmoodi, Kalantari, and Ghaslani (2014) conducted a study to investigate the Self-regulation learning strategies which was often used by English as a foreign language (EFL) leaners in Iran. They explored not only the self-regulation strategies, and the relationship between motivation and Self-regulation learning (SRL), but also the SRL and language achievement. They gained data from 130 EFL learners studying at two institutes in Hamedan and Sanandaj. The researchers found that Iranian EFL learners use five Self- regulation learning strategies as follows:

1. Creating relationship between English which has been understood and English which should be learnt.

2. Studying English more whenever they have not understood the subject.

3. Testing English regularly.

4. Trying and thinking about the more enjoyable strategies to learn English.

5. Keeping records of English mastery.

From these five strategies, number one and number four are cognitive strategies, number two is behavioral strategy, number three and number five are metacognitive strategies. Furthermore, this study found that there was a significant relationship between SRL and motivation. It is assumed that self-regulation learning and motivation work hand in hand to clarify students' learning and success in learning English as Foreign Language. Talking about the use of SRL strategies and language achievement, Mahmoodi, Kalantari, and Ghaslani (2014) concluded that there was no clear relationship between SRL and language achievement.

From those previous studies, it has been shown that Self-regulation learning is useful for student to control and maintain students' progress in learning. However, there was no researcher who conducted a study about students' self- regulation in facing the high-stake of university admission, therefore it is essential to conduct a study to explore this area. In this study, the researcher attempted to answer the two formulated problems as follows:

1. What were the contributing factors for some senior high school students to be selfregulated learners?

2. How did the students implement self- regulation in achieving their goals and facing the English test?

\section{METHOD}

This study was a mix methods research which obtained the data by conducting face to face structured interview and delivering questionnaires. Structured interview refers to a situation in which an interviewer asks each respondent a series of pre-established questions with a limited set of response categories (Schwandt, Denzin, \& Lincoln, 1994). Hence, the researcher delivered the same questions to all the respondents. The interviewing sections 
were recorded. Questionnaires were employed to measure the implementation of SelfRegulation toward students. The participants of this study were 12 third year of senior high school students in the first semester who prepared themselves to enroll in some universities. They came from a public one senior high school in Klaten, Indonesia.

The researchers collected the data through questionnaire and interview. First, the researcher delivered questionnaires to the participants about the four phases of selfregulation. Moreover, she conducted interviews to gain deeper understanding about the self regulation activities performed by the participants.

The researchers analyzed the result of the questionnaires and interviews and described the results using narrative inquiry strategy in which the researchers elicited the participants to tell stories in implementing self-regulation to pass the high-stake of university admission test especially in English subject. The researchers followed the theory of (Ary, Jacobs, Sorensen, \& Razavieh, 2010) that in narrative inquiry, the researchers examine the stories people, tell about their lives and co-construct a narrative analysis of those stories. The researchers and the participants' stories have an equal voice in determining the meanings attributed to the experiences. In this study, the researchers analyzed every step of self-regulation.

\section{FINDINGS AND DISCUSSION}

What were the contributing factors for some senior high school students to be selfregulated learners?

Table 2. Senior High School Students' Expectation to Universities And Their Reasons

\begin{tabular}{|c|c|c|c|}
\hline $\begin{array}{c}\text { Faculty } \\
\text { Expectation }\end{array}$ & University & $\begin{array}{l}\text { Number of } \\
\text { students }\end{array}$ & Reason \\
\hline \multirow{2}{*}{$\begin{array}{l}\text { Faculty of } \\
\text { Medicine }\end{array}$} & UGM & 1 student & $\begin{array}{l}\text { The participant wants to help and cure people from } \\
\text { illness }\end{array}$ \\
\hline & UNS & 1 student & $\begin{array}{l}\text { The participant wants a great job which can produce } \\
\text { much money }\end{array}$ \\
\hline $\begin{array}{l}\text { Department of } \\
\text { Taxation }\end{array}$ & STAN & 3 students & $\begin{array}{l}\text { The participants expect a guaranteed and great job } \\
\text { after graduation, } \\
\text { The participants want to get much money }\end{array}$ \\
\hline \multirow{2}{*}{$\begin{array}{l}\text { Accounting } \\
\text { Department }\end{array}$} & \multirow{2}{*}{ STAN } & \multirow{2}{*}{2 students } & $\begin{array}{l}\text { The parents give instruction and have a good belief } \\
\text { about Accounting Department }\end{array}$ \\
\hline & & & $\begin{array}{l}\text { The participants expect a great job which can produce } \\
\text { much money and make good life. }\end{array}$ \\
\hline $\begin{array}{l}\text { Faculty of } \\
\text { Psychology }\end{array}$ & UNS & 1 student & The participant feels enjoy learning about psychology \\
\hline $\begin{array}{l}\text { Faculty of } \\
\text { Engineering }\end{array}$ & ITB & 3 students & $\begin{array}{l}\text { The participants expect great job. } \\
\text { The study program is appropriate to their talent and } \\
\text { capability. }\end{array}$ \\
\hline $\begin{array}{l}\text { Faculty of } \\
\text { Nursery }\end{array}$ & Politekes & 1 student & It is a useful job for human being. \\
\hline
\end{tabular}

Those senior high school students expected to continue their study in the famous, best and reputable universities in Indonesia. There were 5 universities chosen by this research's 
participants. Those were UGM, STAN, UNS, ITB and Politekes. Students were motivated to continue studying at those Universities because of many reasons. There were 2 participants who wanted to be doctors. They wanted to study in UGM and UNS. Student A wanted to be a doctor because she had a very glorious idea to cure people, meanwhile student $F$ wanted to be a doctor because she thought that she could earn much money. Furthermore, there were 3 students who really wanted to study in the Department of Taxation at STAN. These 3 participants had the same reason to study there. A great future job was the main reason for them to enroll at STAN. There were 2 students wanted to continue their study I $n$ Accounting Department at STAN too. One student had the same reason as the previous three students that they wanted a great future safe job guaranteed. Whereas, a student who wanted to enroll at STAN because of parents' instruction. In relation to parents' instruction of child learning, Dasen (2003) as quoted by (Ireson, 2008) asserts that parents have a set of beliefs and ideas about the competencies they expect children to acquire.

Moreover, there was a student who decided to enroll in the Faculty of Psychology at UNS because she just wanted to be a Psychologist without any other expectation. In addition, there were 3 students who decided to study at ITB. These three students had the same 2 reasons to enroll at ITB. The first reason was they wanted to get a great job in the future, while the second reason was, they thought that they had good capabilities and talents to study at ITB. The last participant wanted to be a nurse and continued study at POLITEKES. The reason for her to be a nurse was because of a nurse is a glorious job which is useful for people surround her.

These findings have shown that all the participants were seriously expecting great and famous Universities to enroll. They kept discipline and prepared themselves to pass the highstake of university admission test. All participants had beliefs and potentialities to achieve their own goal by taking actions in study hard. They determined their own goal must be achieved. It had strong relationship with the theory by Schunk et al., (2002) that motivation is the process whereby goal-directed activity is instigated and sustained. All the participants have defined their reasons why they wanted to enroll certain universities, and they seriously wanted to pass the test. They did hard effort and study hard. They were self-regulated learners. Zimmerman (1998) as quoted by (Ireson, 2008) also strengthened Schunk, Pintrich and Meece's statement that when considered in relation to academic learning, self-regulation has been defined as self-generated thoughts, feelings, and actions for attaining academic goals.

\section{How did the students implement self- regulation in achieving their goals?}

There are 4 phases in implementing self-regulation as discussed by Pintrich (2000) as follows: forethought and planning, monitoring, controlling, and reflecting. In this part, the researchers discussed how senior high school students implemented the 4 phases of selfregulation in achieving their goals or in facing the English test. 


\section{How the fore thought and planning phase were implemented?}

Table 3. The Implementation of Forethought And Planning Phase

\begin{tabular}{|c|c|c|}
\hline \multicolumn{3}{|c|}{ Forethought and Planning } \\
\hline \multirow{3}{*}{ Cognition } & Setting goal & $\begin{array}{l}\text { All participants have set their goals to a certain study } \\
\text { program at a University }\end{array}$ \\
\hline & \multirow{2}{*}{ Metacognitive Knowledge } & $\begin{array}{l}8 \text { participants have understood their own potentialities } \\
\text { and capabilities }\end{array}$ \\
\hline & & $\begin{array}{l}4 \text { participants have not measured their own potentialities } \\
\text { and capabilities }\end{array}$ \\
\hline \multicolumn{2}{|c|}{ Motivation / self-efficacy } & $\begin{array}{l}\text { All participants had beliefs and believed that they will } \\
\text { be able to pass the high-stake of university admission } \\
\text { test especially English Subject }\end{array}$ \\
\hline \multicolumn{2}{|c|}{ Behavior / Study Plan } & $\begin{array}{l}\text { All participants planned to study at home around } 1 \text { hour } \\
\text { every day for English subject }\end{array}$ \\
\hline
\end{tabular}

In the first phase, fore thought and planning section, this study found that all the participants had their own goals. The goal for every participant was to pass the high-stake of university admission test at their dreamed universities.

There were eight participants who had understood their potentialities and capabilities before they made their study plans. These eight participants were related to the metacognitive knowledge theory from Pintrich and Schunk (2002) that it is important that students have an accurate perception of their knowledge base and expertise rather than an inflated or inaccurate self-knowledge or self-awareness. Meanwhile, there were 4 participants who have not measured their potential in mastering English to face the test. These four participants have not implemented metacognitive knowledge step.

Analyzing the participants' motivation in the beginning step, this study found that all participants believed that they would be able to pass the English test of the high-stake of university admission test. All participants in this study had high self-efficacy level. In accordance with Bandura (1986) as quoted by Smith (2009) statement that self-efficacy refers to self-judgment or beliefs of their capability to organize and execute courses of action required to achieve designated types of performance. In this study, all the participants have believed that they could be able to pass the English Test. Believing ourselves to pass the test; it could help them to keep their study regulation until they met the demand of the test.

Moreover, all the participants have arranged the study plan and schedule. All the participants arranged an hour every day to study English subject. They designed teaching and learning strategies such us understanding materials and doing worksheet. Pintrich and Zeidner (2000) were right that self-regulation is a systematic process of human behavior that involves setting personal goals and steering behavior toward the achievement of established goals.

Analyzing the implementation of senior high school students' self-regulation in the forethought and planning phase, all the participants hold a good step even though there were 
4 students have not understood and measured their own potentialities and capabilities to face the English test. Believing their capabilities or having high self-efficacy, students could be able to monitor their learning until they achieved their goals.

\section{How the monitoring phase was implemented?}

Table 4. The Implementation of Monitoring Phase

\begin{tabular}{lll}
\hline & \multicolumn{2}{c}{ Monitoring Phase } \\
\hline \multirow{2}{*}{ Metacognition Awareness } & Doing worksheet & All participants \\
\cline { 2 - 3 } & Comparing scores with friends & All participants \\
\cline { 2 - 3 } & Finding easy way to do the worksheet & $\begin{array}{l}\text { 1 participant } \\
\text { (Student C) }\end{array}$ \\
\cline { 2 - 3 } Awareness of Self - Efficacy & Studying a topic every day & $\begin{array}{l}\text { 1 participant } \\
\text { (Student A) }\end{array}$ \\
\hline Time Management / Effort & Ull participants always believed they would be able to enroll at the \\
\hline
\end{tabular}

In the monitoring phase, all participants checked their capabilities and potentials in mastering English by doing the worksheets and comparing their scores to others' scores. In this phase, the participants have implemented a theory by Anderson (2002) which states that metacognitive ability to select, use, and monitor particular strategies in a given context for a specific purpose means that the learner can think and make conscious decisions about their own learning processes. In this study, all the participants had the metacognition awareness by measuring their improvement in learning English from the result of doing worksheets.

Student $\mathrm{C}$ had another strategy to learn English: she tried to find different ways in doing the worksheet. Students who pursue learning or mastery goals strive to increase their competence, understand or master something new. They are concerned with improvements in their own learning and are prepared to undertake challenging tasks (Ireson, 2008) Whereas, student A created different strategy for learning: she studied and mastered a new topic every day.

Furthermore, all the participants never decreased their motivation to learn. They kept studying as the schedule arrangement. In this case, all the participants applied Ireson (2008) statement that monitoring involves awareness of actions and their outcomes, which provides information to enable the learner to control cognitive, motivational, behavioral factors. Students monitor their scores in doing worksheet to know their learning performance. Knowing a learning outcome was useful to monitor their self-efficacy awareness as mentioned in the Bandura (1991) statement as quoted by Abun (2018). Abun agrees that in terms of self-monitoring, students cannot influence their own motivation and action very well if they do not pay adequate attention to their own performances, the conditions under which they occur, and the immediate and distal effects they produce.

In this phase, all participants comprehended and understood clearly that doing worksheet, comparing scores with others, learning a topic one day, and finding ways to do the 
worksheet, were good strategies to monitor their potentials and capabilities in preparation to face the test. They did this monitoring phase anytime they needed at least once in a week.

\section{How the controlling phase was implemented?}

Table 5. The Implementation Of Controlling Phase

\begin{tabular}{|c|c|c|c|}
\hline \multicolumn{4}{|c|}{ Controlling Phase } \\
\hline \multirow[t]{4}{*}{ Cognitive } & \multirow[t]{4}{*}{$\begin{array}{l}\text { Metacognitive } \\
\text { Strategy }\end{array}$} & $\begin{array}{l}\text { Checking and comparing the } \\
\text { worksheet scores every week }\end{array}$ & All participants \\
\hline & & $\begin{array}{l}\text { Acknowledging and } \\
\text { understanding the materials }\end{array}$ & $\begin{array}{l}4 \text { participants } \\
\text { (Students A, H, I, L) }\end{array}$ \\
\hline & & Checking level of difficulties & $\begin{array}{l}3 \text { participants } \\
\text { (Students } \mathrm{G}, \mathrm{J}, \mathrm{E})\end{array}$ \\
\hline & & Making summaries & $\begin{array}{l}1 \text { participant } \\
\text { (Student C) }\end{array}$ \\
\hline \multirow[t]{2}{*}{ Behavior } & $\begin{array}{l}\text { Using spare time } \\
\text { for studying }\end{array}$ & \multicolumn{2}{|l|}{ All participants } \\
\hline & Making note & \multicolumn{2}{|l|}{$\begin{array}{l}4 \text { participants } \\
\text { (Students } A, B, D, H)\end{array}$} \\
\hline Motivation & $\begin{array}{l}\text { Maintaining } \\
\text { motivation }\end{array}$ & \multicolumn{2}{|c|}{$\begin{array}{l}\text { All participants maintained and even improved their motivation in } \\
\text { studying English subject }\end{array}$} \\
\hline
\end{tabular}

Analyzing the implementation of controlling phase, the researchers found that the participants controlled their learning by many kinds of actions. Student $\mathrm{C}$ made the summary of English material and he compared the worksheet score every weekend to his worksheet previous scores. Student E, G and J checked the level of material difficulties. Moreover, students A, H, I, L tried to understand all the materials. All of participants did the same metacognitive strategy by comparing the result of doing worksheet gradually. According to Ponnusamy and Gentry (2010) as quoted by Mcfarland (2013), a metacognitive strategy has to be developed and implemented in order to redefine the learning outcomes and this can only be accomplished by empowering students, making them stakeholders in their own learning, and consequently, making them responsible for their own learning processes. This study found that comparing worksheet scores to their previous worksheet scores were useful to know the effectiveness of their learning strategies. This case had a strong relationship with the theory from Duval and Wicklund (1972) as quoted by Abun (2018) that comprehending one's self is another factor that can influence self-regulation in which people focus their attention inward and they tend to compare their present state with a relevant standard.

During the self- regulation learning, this study found that no participants gave up. All of them were able to maintain their motivation to study hard. Moreover, they had strong motivation to study in their spare times or holidays because they remembered about their own responsibilities and dreams exactly to enroll studying in the best, famous and reputable universities in Indonesia.

Observing their behaviors in implementing self-regulation learning, the participants in this study kept focus on the learning duty. The refreshing activities they did was only gathering and having dinner together with their families. They never wanted to go far away 
for holiday. Furthermore, they never touched any kind of online games because they thought that it could disturb their concentration and study.

\section{How the reflecting phase was implemented?}

Table 6. The Implementation of Reflecting Phase

\begin{tabular}{lll}
\hline & \multicolumn{2}{c}{ Reflection Phase } \\
\hline \multirow{2}{*}{ Cognitive Judgment } & $\begin{array}{l}\text { Believing that their strategies in learning were } \\
\text { good and need to be continued }\end{array}$ & 10 participants \\
\cline { 2 - 3 } Bsking help to the teacher about the better & 2 participants \\
strategies in learning & $\begin{array}{l}\text { Keeping learning until facing the high-stake of } \\
\text { university admission test. Be more focus and } \\
\text { effective learning activities }\end{array}$ & All participants \\
\hline Motivation & $\begin{array}{l}\text { All participants were enthusiastic to study and to prepare the high-stake of university } \\
\text { admission test. }\end{array}$ \\
\hline
\end{tabular}

In the last phase, namely in the reflecting section, this study found that 10 participants believed their strategy as in doing worksheet and evaluating their present scores and previous scores were good and appropriate strategies to achieve their goals. Meanwhile there were 2 participants who needed to seek helps to the teachers because they did not believe that their learning strategies were appropriate to achieve their goals. This step was related to the above theory mentioned by Schraw and Dennison (1994) as quoted by Mcfarland (2013) who stated that students with self-regulation study do better at paying attention. They use learning strategies more effectively, and they are more aware when they did not comprehend something they attempted to learn. In this case, it was a very good step when students felt that their strategies were not appropriate to achieve their goal, they could find any suggestions or help from teachers to have a new learning strategy.

Moreover, this study found that all of participants kept enthusiast in achieving their goals. All participants applied Zimmerman (1989 \& 1995) as quoted by Mcfarland (2013) the degree to which learners are motivated to self-regulate depends on their commitment to their personal goals and on the self-efficacy beliefs they hold about their academic capabilities. The goals to be achieved were engendered substantial strong factor to increase commitment in planning, monitoring, controlling and reflecting. Self-regulated students mostly had strong discipline.

\section{CONCLUSION}

In this study, the researchers have discussed senior high school self-regulation in facing the English high-stake of university admission test. All participants did self-regulation learning in order to achieve their goals to enroll study at a famous, big and reputable university such as ITB, UGM, UNS, STAN and Politekes. To be self-regulated learners they had implemented 4 conditioned phases, namely forethought and planning, monitoring, controlling and reflecting phase. 
In the forethought and planning phase, all the participants hold a good step even though they had set their goals and had high self-efficacy to achieve their goals. There were 8 participants performed metacognitive knowledge although four of those students still have not understood and measured their own potentials and capabilities in mastering English subject. In the second phase, the monitoring phase, the most strategies applied by the participants were doing worksheet and comparing the scores to other friend's scores. All the participants kept enthusiastic to study and maintained their self-efficacy. Moreover, in the controlling phase, the strategies used by all participants were doing worksheet and comparing their present scores with their previous scores every weekend. In this phase, all participants appeared that they never gave up and kept studying every day. In the last phase, the reflecting phase, there were 10 participants who believed their strategy as doing worksheet and evaluating their scores were good and appropriate strategies to achieve their goals. However, there were 2 participants who sought for assistance to the teachers about the other strategy which could be implemented.

This study focused on the implementation of senior high school Students' selfregulation process in the first semester. The students did self-regulation to achieve certain goals: they wanted to enroll and be accepted in some famous and reputable universities in Indonesia. The researchers suggested to other educational researchers to carry out studies related to the results of being self-regulated in learning English related to universities contexts and settings.

\section{REFERENCES}

Abun, D. (2018). Academic Self-Regulation of STEM of Senior High School Students of Divine Word Colleges in Region I , Philippines and Their Academic Performance Academic Self-Regulation of STEM of Senior High School Students of Divine Word Colleges in Region I , Philippi, (May). https://doi.org/10.21522/TIJAR.2014.05.01.Art003

Ames, C. (1992). Classrooms: Goals, structures, and student motivation. Journal of Educational Psychology, 84(3), 261.

Anderson, N. J. (2002). The Role of Metacognition in Second Language Teaching and Learning. ERIC Digest.

Ary, D., Jacobs, L. C., Sorensen, C., \& Razavieh, A. (2010). Introduction to research in education eight edition. Wadsworth: Cengage Learning.

Çırak, Y. (2016). University Entrance Exams from the Perspective of Senior High School Students. Journal of Education and Training Studies, 4(9), 177-185. https://doi.org/10.11114/jets.v4i9.1773

Ireson, J. (2008). Learners, learning and educational activity. Routledge.

Leaver, B. Lou, Ehrman, M., \& Shekhtman, B. (2005). Achieving success in second language 
acquisition. Cambridge University Press.

Mahmoodi, M. H., Kalantari, B., \& Ghaslani, R. (2014). Self-Regulated Learning (SRL), Motivation and Language Achievement of Iranian EFL Learners. Procedia - Social and Behavioral Sciences, 98, 1062-1068. https://doi.org/10.1016/j.sbspro.2014.03.517

Mcfarland, M. (2013). Increasing the metacognitive awareness of high school students.

Pintrich, P. R. (2000a). Multiple goals, multiple pathways: The role of goal orientation in learning and achievement. Journal of Educational Psychology, 92(3), 544.

Pintrich, P. R. (2000b). The Role of Goal Orientation in Self-Regulated Learning. Handbook of Self-Regulation, 451-502. https://doi.org/10.1016/b978-012109890-2/50043-3

Pintrich, P. R., \& Schunk, D. H. (2002). Motivation in education: Theory, research, and applications. Prentice Hall.

Pintrich, P. R., \& Zeidner, M. (2000). Handbook of self-regulation. Elsevier Science \& Technology.

Schunk, D. H., Meece, J. L., \& Pintrich, P. R. (2002). Goals and goal orientations. Motivation in Education: Theory, Research, and Applications, 170-209.

Schwandt, T. A., Denzin, N. K., \& Lincoln, Y. S. (1994). Handbook of qualitative research. Londres, Ed: Denzin \& Lincoln.

Seker, M. (2016). The use of self-regulation strategies by foreign language learners and its role in language achievement. Language Teaching Research, 20(5), 600-618. https://doi.org/10.1177/1362168815578550

Smith, L. (2009). Changes in student motivation over the final year of high school. The Journal of Educational Enquiry, 5(2).

Wold, J. B. (2006). Difficulties in Learning English As a Second Or Foreign Language.

Zimmerman, B. J. (1989). A Social Cognitive View of Self-Regulated Academic Learning. Journal of Educational Psychology, 81(3), 329-339. https://doi.org/10.1037/00220663.81.3.329

Zimmerman, B. J., Bonner, S., \& Kovach, R. (1996). Developing self-regulated learners: Beyond achievement to self-efficacy. American Psychological Association. 